\title{
Het Belgische Jiddischland. Een politieke geschiedenis van de joodse gemeenschappen in België tussen de twee wereldoorlogen
}

\section{Rudi Van Doorslaer}

\section{(2) OpenEdition Journals}

Édition électronique

URL : http://journals.openedition.org/cmc/365

ISSN : 2684-3080

Éditeur

Fondation de la Mémoire Contemporaine

Édition imprimée

Date de publication : 1 décembre 2014

Pagination : 43-66

ISSN : 1377-1256

Référence électronique

Rudi Van Doorslaer, « Het Belgische Jiddischland. Een politieke geschiedenis van de joodse gemeenschappen in België tussen de twee wereldoorlogen », Les Cahiers de la Mémoire Contemporaine [Online], 11 | 2014, Online op 05 novembre 2019, geraadpleegd op 08 septembre 2020. URL : http:// journals.openedition.org/cmc/365 


\section{Het Belgische Jiddischland \\ Een politieke geschiedenis van de joodse gemeenschappen in België tussen de twee wereldoorlogen}

\section{Rudi Van Doorslaer}

De interesse voor de joodse geschiedenis in België is de voorbije jaren, zowel bij de academici als bij het brede publiek, steeds groot gebleven. Met de opening in 2012 van de nieuwe Kazerne Dossin in Mechelen is die belangstelling in Vlaanderen-België wellicht intenser dan ooit. Toch is de kennis over afkomst, opvattingen en leven van de joodse gemeenschappen in België voor de Holocaust veeleer oppervlakkig en niet zelden te zeer beïnvloed door de wijze waarop deze gemeenschappen vandaag worden gepercipieerd. Hoe onvoldragen ook, lijkt het mij nuttig een synthese van hun politieke geschiedenis te publiceren.

De oorsprong van dit onderzoek gaat terug tot mijn doctoraatsstudie over de revolutionaire joodse migranten in België in het interbellum ${ }^{1}$. De focus lag daarin op de relatie tussen de joodse migratie uit Oost- en Centraal Europa en het communisme, maar het onderzoek kon niet anders dan ook het breder perspectief bekijken. Dit breder perspectief was uiteraard de sociale, culturele en politieke context van de joodse gemeenschappen in België. Ik ben van deze brede focus vertrokken om dit politiek palet te schetsen, waarbij vooral de betekenis van de zionistische stroming op een heel andere wijze op de voorgrond is gekomen dan in mijn vorige publicaties. Niet onbelangrijk is wel nog te melden dat er de voorbije jaren geen fundamenteel onderzoek meer is uitgevoerd over deze specifieke materie op doctoraatsniveau. Wel was er het onderzoek naar de betrokkenheid van de Belgische overheid bij de Jodenvervolging, dat in 2007 onder de titel Gewillig Belgï̈ werd gepubliceerd ${ }^{2}$. Het

\footnotetext{
1 R. Van Doorslaer, Kinderen van het getto. Joodse revolutionairen in Belgie, 1925-1940. AntwerpenBaarn/Gent, 1996. Id., Enfants du Ghetto. Juifs révolutionnaires en Belgique, 1925-1940. Brussel, 1997. ${ }^{2}$ R. Van Doorslaer (red.), E. Debruyne, Fr. Seberechts, N. Wouters (i.s.m. L. Saerens), Gewillig België. Overheid en Jodenvervolging tijdens de Tweede Wereldoorlog, Antwerpen-Brussel, 2007.
} 
deelonderzoek dat Emmanuel Debruyne in dat kader had uitgevoerd over de geschiedenis van de Duitse vluchtelingen aan de vooravond van de Tweede Wereldoorlog vormde een substantiële aanvulling bij deze synthese. In dat opzicht geeft deze tekst - detailaspecten wellicht niet te na gesproken - m.i. de stand van zaken op dit onderzoeksterrein weer.

\section{Nieuwe migranten importeren het Jiddischland}

Aan de vooravond van de Eerste Wereldoorlog woonden er naar schatting zowat 40.000 Joden in België. Het talrijkst verbleven ze in Brussel en Antwerpen, maar o.m. ook in Luik, Charleroi, Gent, Aarlen en enkele kleinere steden of gemeenten waren er kleine kernen van joodse bewoning. Als gevolg van de oorlog kwam er een grote uittocht op gang. Vele Joden waren Duitse of vooral Oostenrijks-Hongaarse onderdanen en werden als gevolg daarvan gedwongen het land te verlaten. De meeste onder hen namen de vlucht naar Nederland of GrootBrittannië. In ieder geval was de joodse aanwezigheid na de bevrijding van het land in 1918 zeer sterk teruggelopen.

Toen, twee decennia later, de Tweede Wereldoorlog uitbrak verbleven er evenwel opnieuw minstens 70.000 Joden in België. Vele vluchtelingen kwamen na afloop van de Eerste Wereldoorlog terug, maar de overgrote meerderheid onder hen waren toch nieuwe migranten die zich hoofdzakelijk tussen 1925 en 1932 in België hadden gevestigd. Deze vele duizenden nieuwe joodse migranten wijzigden ingrijpend het sociaal, cultureel en politiek profiel van de joodse gemeenschap(pen) in België. De joodse migranten die in de jaren 1920 naar België kwamen, waren hoofdzakelijk afkomstig uit economisch achtergebleven stedelijke en kleinsteedse regio's uit Oost- en Centraal Europa. Dit maakt, zoals zal blijken, dat om diverse redenen de joodse migratie in vergelijking met de al even talrijke niet-joodse migratie bijzonder was. Tegen het einde van de jaren dertig ontstond er opnieuw een andere situatie door de toevloed van vele duizenden joodse vluchtelingen uit Duitsland en Oostenrijk als gevolg van de anti-joodse vervolgingen in nazi-Duitsland. 
De Oost-Europese Joden vormden in de periode 1880-1930 de grootste "emigratienatie" ter wereld. Zowat een derde onder hen verliet in die halve eeuw haar of zijn geboorteland. Het binnendringen van het kapitalisme in Oost-Europa in de tweede helft van de 19de eeuw kan als de belangrijkste oorzaak voor die massale migratie worden aangewezen. Daardoor desintegreerden namelijk de traditionele economische structuren van de joodse bevolking.Naast deze sociaaleconomische push-factor, speelden eveneens demografische en politieke elementen een rol.De snelle aangroei van de joodse bevolking in de 19de eeuw heeft ongetwijfeld de druk verhoogd. De sociale ontwrichting van de traditionele Oost-Europese samenlevingen had ook politieke gevolgen, die zich vooral vertaalden in de opkomst van het nationalisme. Parallel daaraan wakkerde het antisemitisme aan dat in OostEuropa kon bogen op een oude traditie.

Tot het begin van de jaren 1920 richtte de joodse migratie zich voornamelijk op de VSA en in mindere mate op Argentinië en Brazilië. Ook Europa, en in het bijzonder Frankrijk, Groot-Brittannië en Duitsland, kenden een aanzienlijke joodse inwijking. Na de Eerste Wereldoorlog werden de grenzen in vele landen gesloten. In de VSA, het immigratieland bij uitstek, vormde de Immigration Act van 1924 een drastische wijziging van het tot dan toe gevoerde beleid. Nadien werd zowel in België als in Frankrijk de joodse immigratie echt aanzienlijk. Beide landen bleven, in tegenstelling tot andere Europese landen zoals Groot-Brittannië, Duitsland en zeker Nederland, in de jaren twintig een liberale migratiepolitiek voeren. Dat veranderde in het begin van de jaren 1930, toen onder druk van de economische crisis ook België immigratiebeperkingen invoerde. Een drastische wijziging kwam er echter pas in 1939-1940, toen als gevolg van de toegenomen oorlogsdreiging het veiligheidsstreven ging primeren ${ }^{3}$.

\footnotetext{
${ }^{3}$ J.-Ph. Schreiber, L'immigration juive en Belgique, du Moyen Âge à nos jours, in A. Morelli (red.), Histoire des étrangers et de l'immigration en Belgique de la préhistoire à nos jours, Brussel, 1992, pp. 207-231 ; Fr. Caestecker, Het vreemdelingenbeleid in de tussenoorlogse periode, 1927-1937. Een onderzoek naar de belangen achter het racisme, licientaatsverhandeling, RUG, 1983 ; Id., Ongewenste gasten? Joodse vluchtelingen en migranten in de dertiger jaren, Brussel, 1993 ; Id., Alien Policy in Belgium, 1840-1940. The Creation of Refugees, Guestworkers and Illegal Aliens, Oxford-New York, 2000.J. Stengers, Émigration et immigration en Belgique au XIX $X^{e}$ siècle et au $X X^{e}$ siècle, Brussel, Académie royale des Sciences d'Outre-Mer, XLVI-5, 1978, p. 78.
} 
In de jaren 1920 kende België ook een aanzienlijke vooral Italiaanse en Poolse migratie. Die migranten werden door en voor de Belgische industrie geworven. Zij kwamen meestal in groep naar België om een tijdelijk tekort in bepaalde sectoren van de arbeidsmarkt, voornamelijk de mijnbouw en staalnijverheid, op te vullen. Op dit vlak kan er een essentieel onderscheid met de joodse migratie worden aangestipt. De joodse migranten kwamen meestal individueel of in familieverband en op eigen initiatief naar België. Zij hadden, in tegenstelling tot de andere migranten, veelal niet de intentie nog terug te keren ${ }^{4}$.

Ook het sociale profiel van de joodse migranten zag er anders uit. De Italiaanse en Poolse migranten werkten hoofdzakelijk in de zware industriële sectoren en werden bijgevolg naar de - hoofdzakelijk Waalse en Limburgse - industriële regio's gekanaliseerd. De Joden kwamen in de tertiaire sector en in de kleinschalige, artisanale luxegoederennijverheid terecht. Zij vestigden zich bijgevolg voornamelijk in de grote agglomeraties Brussel en Antwerpen en in mindere mate ook in Luik en Charleroi ${ }^{5}$. Ook aan de pull-zijde vertoonde de joodse migratie dus specifieke kenmerken, wat niet wegneemt dat het relatief hoge welvaartspeil in België in de jaren 1920 ongetwijfeld een belangrijke aantrekkingskracht uitoefende op alle migranten, ook de joodse.

De joodse sectoren bij uitstek waren de confectie in Antwerpen en Brussel, de marokijnsector in Brussel en de diamant in Antwerpen ${ }^{6}$. Ook in de voedingsnijverheid en onder de studentenbevolking trof men in de jaren twintig en dertig relatief veel Joden aan. In feite is er in de meeste van die sectoren geen "aantrekking" geweest van vreemde arbeidskrachten. De lage industriële ontwikkelingsgraad in die sectoren liet kleine joodse patroons toe met meestal joodse werklui een zaak op te starten. De minstens zo talrijke joodse handelaars, winkeliers en

${ }^{4} \mathrm{~J}$. Ph. Schreiber, Les juifs de Belgique face à la montée de l'antisémitisme nazi (1933-1939), licentiaatsverhandeling, ULB, 1984, pp. 25-29 en pp. 41-43.

${ }^{5}$ A. Vanderputten, L'immigration polonaise dans le bassin de Charleroi à travers le prisme d'un millier d'immigrés arrivés en 1929, licentiaatsverhandeling, UCL, section d'histoire, 1983, pp. 9899.

${ }^{6} \mathrm{~K}$. Liberman, Les Juifs dans l'industrie et le commerce belges. I. La maroquinerie, Antwerpen, Comité pour la défense des droits juifs, 1934 ; II. Industrie et commerce diamantaires belges, Brussel, 1935. 
leurders stonden in voor de verkoop van die goederen, waardoor er in feite een parallel economisch circuit ontstond?

De joodse migranten bekleedden bijgevolg een specifieke plaats in de Belgische economie. In het begin van de jaren 1930 werd de kleinschalige en ambachtelijke luxegoederenproductie en -handel zwaar getroffen door de economische crisis. De joodse migrantenbevolking verpauperde en twee fenomenen werden door de crisistoestand in het bijzonder versterkt. De gesalarieerde arbeid nam af en werd nog meer door huisnijverheid en stukloon vervangen ${ }^{8}$. Vele kleine handelszaken gingen failliet en de leurderhandel bloeide op. Onder druk van de toegenomen concurrentie op de kleinhandelsmarkt ijverden vooral katholieke middenstandsverenigingen voor maatregelen tegen joodse handelaars, marskramers en leurders. Deze concurrentiestrijd kan als een belangrijk verklaringselement worden gezien voor het toenemende antisemitisme tijdens de tweede helft van de jaren 1930 in Brussel en Antwerpen, maar ook bijvoorbeeld in Limburg. Eveneens onder bepaalde groepen arbeiders, zoals in de kleding en de diamant, nam de sociale druk toe. Ook dat leidde tot uitgesproken xenofobe reacties.

Op nog twee andere punten was de joodse migratie specifiek. De geografische concentratie in bepaalde wijken van grote steden, bij voorkeur rond de stations waar de nieuwbakken migranten neerstreken, is een kenmerk van de joodse bewoning van de jaren 1920 en 1930. Daarbij aansluitend kregen die wijken een cultureel cachet (winkels met Jiddische opschriften, synagogen, Joden in traditionele kaftans... $)^{9}$. De orthodoxe Joden vormden voor de Tweede Wereldoorlog slechts een minderheid, maar de joodse migratie werd door hun zichtbaarheid toch door velen met die groep geassocieerd. Voor het eerst werd België daardoor geconfronteerd met een groep vreemdelingen die samenwoonden, een eigen taal spraken (het Jiddisch) en een eigen religieuze en culturele leefwereld afficheerden. De joodse migratie was dus ook in de graad van religieuze specificiteit en culturele herkenbaarheid bijzonder en in dat opzicht een voorloper van de Turkse en Maghrebijnse migratie in de tweede helft van de 20ste eeuw.

\footnotetext{
${ }^{7}$ K. Liberman, « Les marchands ambulants juifs en Belgique », in Unser Tagblat, 27 april 1936.

${ }^{8}$ F. Baudhuin, Histoire économique de la Belgique 1914-1939, Brussel, 1948, deel 2, p. 103.

${ }^{9}$ J. Stengers, op. cit., p. 78.
} 


\section{Een politiek profiel}

De gelijkberechtiging, die in het voetspoor van de Franse revolutie werd doorgevoerd, doorbrak ook in België in de loop van de 19de eeuw het eeuwenoude joodse getto. De joden streefden ernaar opgenomen te worden in de nationale gemeenschap en speelden een opmerkelijke rol in het bank- en financiewezen en - zij het in mindere mate - in de industrie. Een meerderheid van de Joden in België bezat voor het laatste kwart van de 19de eeuw de Belgische nationaliteit. De joodse identiteit vond zijn uitdrukking in de semireligieuze Gemeenten met hun traditionele joodse caritatieve werken die overkoepeld werden door het Centraal Israëlitisch Consistorie van België. Dit grotendeels burgerlijk joods milieu was veeleer liberaal en Belgicistisch georiënteerd. Dit was een afspiegeling van het assimilatieproces dat ook in de taal (de verfransing) tot uiting kwam ${ }^{10}$.

Met de opkomst in Europa van de nationalistische tendensen tijdens het laatste kwart van de 19de eeuw en de Dreyfus-affaire in Frankrijk, groeide bij vele Joden opnieuw twijfel. Welke waarborgen bood deze assimilatie voor de toekomst? Rond dezelfde tijd, grosso modo tussen 1880 en 1914, kwamen enkele duizenden Joden uit Oostenrijks Galicië en Rusland naar België afgezakt. Met hen manifesteerde het Oost-Europees Jodendom zich in ons land. Ook speelde Antwerpen in die periode een belangrijke rol als transithaven voor de joodse emigratie naar Noord- en Latijns Amerika. Toen kwamen ook de eerste joodse studenten, vooral naar de universiteiten van Luik en Gent, afgezakt ${ }^{11}$. Het was deze generatie migranten die het religieus-orthodox Jodendom en het zionisme in België importeerde. Nieuwe orthodoxe religieuze Gemeenten werden opgericht, voornamelijk in Antwerpen.In 1898 werd een eerste liberale zionistische vereniging gesticht in België en in 1905 werd de Belgische Zionistische Federatie (BZF) boven de doopvont gehouden. Voor 1914

\footnotetext{
${ }^{10} \mathrm{~J} .-\mathrm{Ph}$. Schreiber,Politique et religion. Le Consistoire Central Israélite de Belgique au XIXe siècle, Brussel, 1995.

11A. Van Acker, Slavische studenten aan de RUG (1885-1914).Een evocatie, RUGent, 1986.
} 
zorgden vooral levensbeschouwelijke tegenstellingen voor verdeeldheid in de schoot van de $\mathrm{BZF}^{12}$.

Met de massale immigratie van arme Oost-Europese Joden na de Eerste Wereldoorlog onderging de joodse politieke landkaart opnieuw een grondige wijziging. Deze wijziging herschikte de verhouding tussen de kleine groep Belgische joden en de joodse vreemdelingen en leidde tot een toenemende politisering.

Eén van de meest opvallende kenmerken van het veranderingsproces dat het Oost-Europees Jodendom vanaf het laatste kwart van de 19de eeuw een ander aanzien gaf, was de snelle laïcisering. Dit betekende niet dat de godsdienst geen factor van betekenis bleef in de mentale leefwereld van vele joodse migranten. Uit diverse elementen blijkt dat tijdens het interbellum de invloed van de godsdienst - en van het orthodoxe Jodendom in het bijzonder - in Antwerpen groter was dan in Brussel. De religieuze zionistische partij Misrakhi was veel sterker ingeplant in Antwerpen dan in de hoofdstad. Ook ontplooide de orthodoxe maar uitgesproken antizionistische vereniging Agudath Israël een aanzienlijke activiteit in de Metropool, maar was ze nauwelijks bestaand in Brussel ${ }^{13}$. Verder telde Antwerpen in de jaren dertig drie synagogen en acht gebedsplaatsen, tegenover respectievelijk twee en zes voor Brussel ${ }^{14}$.De Chassidische beweging Beth Hamidrash, waarvan het spirituele centrum zich in het OostGalicische Lvov bevond, werd administratief geleid door de religieuze Gemeente Mah'sike Hadass vanuit Antwerpen ${ }^{15}$.Toch wijzen alle beschikbare indicatoren erop dat de religieuze orthodoxie slechts een secundaire rol speelde in de evolutie van de joodse gemeenschappen in België tijdens het interbellum.

De politieke, culturele en sociale tegenstellingen in de schoot van de joodse gemeenschap in het interbellum kunnen (wellicht al te) schematisch op een vijftal assen worden uitgezet :

${ }^{12}$ J. Verhelst, De Belgische Zionistische Federatie en de oriëntatie van de zionistische beweging (19051914), onuitgegeven.

13Zie o.a. : M. Krajzman, La presse juive en Belgique et aux Pays-Bas. Histoire et analyse qualitative de contenu, Brussel, 1975, p. 42 ; J. Verhelst, op. cit.

${ }^{14}$ Cegesoma, MS10, Rapport Ehlers, p. 35.

${ }^{15}$ Archiwum Akt Nowych (AAN), MSZ, 10.012, Rapport over de Pools-joodse organisaties, pp. 23. 


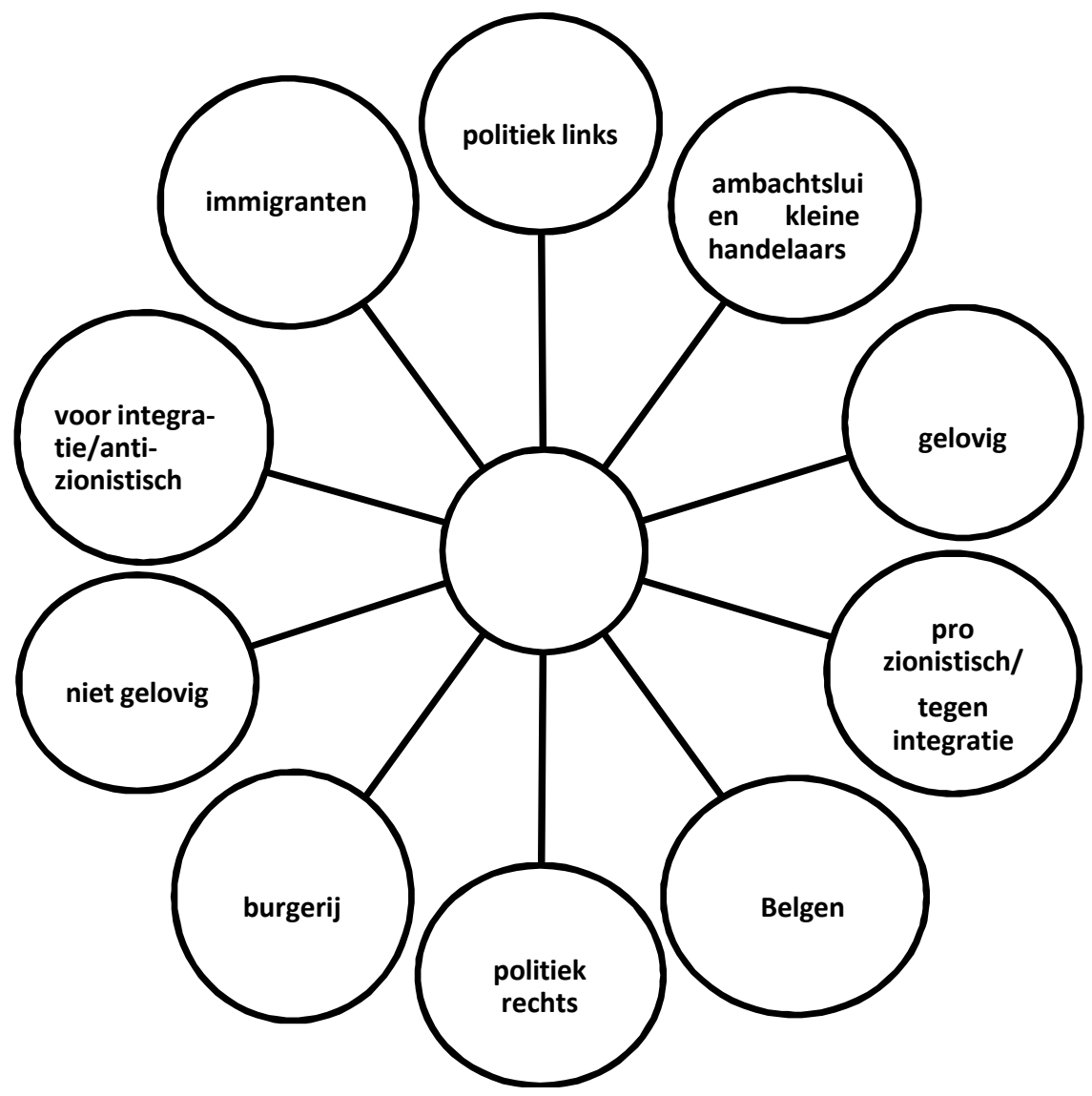

Het zijn deze tegenstellingen die kunnen helpen het complexe joodse politieke landschap te begrijpen. Zij helpen ons in het bijzonder de verschillen tussen Antwerpen en Brussel te doorgronden en de joodse reacties op het antisemitisme en de vervolgingen in Duitsland in de juiste context te plaatsen.

Tegen het midden van de jaren 1930 kwamen er in joodse migrantengemeenschap twee strekkingen duidelijk op de voorgrond: een waaier van zionistische verenigingen enerzijds en de joodse communisten anderzijds. Vooral de toonaangevende zionistische aan- 
wezigheid vormde, in de context van de joodse geschiedenis, een WestEuropees unicum.

\section{De doorbraak van het zionisme}

Wat het zionisme in België betreft kunnen enkele belangrijke evoluties in de jaren twintig en dertig worden aangewezen. Vooreerst nam het aantal zionisten toe en werd de beweging dus gestaag invloedrijker. Belangrijk daarbij was dat het arbeiderszionisme een plaats opeiste naast het burgerlijke en religieuze zionisme. Opvallend is ook dat er in die periode een langzame toenadering op gang kwam tussen de zionistische rechterzijde en de traditionele kringen van het Israëlitische Consistorie. Tenslotte verschoof, onder invloed van zowel de dramatische economische crisis als van het toegenomen antisemitisme en de toevloed van vluchtelingen uit nazi-Duitsland, de aandacht van de zionisten in de late jaren dertig van de voorbereiding van de migratie naar Palestina naar de problemen in de Belgische migratie $^{16}$.

De gestage opgang van het zionisme in België kan als volgt worden geillustreerd. Het aantal ingeschreven kiezers voor het Zionistische Wereldcongres steeg van 788 in 1927 naar 3.812 in 1939. Deze continue vooruitgang werd één maal onderbroken, namelijk in 1935, toen de rechtse en radicaal nationalistische Revisionisten niet meer deelnamen aan de verkiezingen ${ }^{17}$. Het is trouwens opvallend hoe tussen 1929 (toen de Revisionisten voor het eerst deelnamen aan de verkiezingen in België) en 1931, de uitgesproken rechtse zionisten van de kleinste tot de belangrijkste stroming waren uitgegroeid. Deze spectaculaire vooruitgang viel samen met het begin van de economische crisis in België. Het "revisionistisch" zionisme pleitte voor een vrije en ongelimiteerde vestiging van de Joden in Palestina. In 1929 richtten de Belgische Revisionisten ook hun jeugdbeweging Beitar op. Twee jaar later, in 1933 kenden ze een al even grote terugval en vanaf dan beheersten de liberale zionisten en de zionistische arbeiderspartij Poale Tsion

\footnotetext{
${ }^{16}$ J.-Ph. Schreiber, Les Juifs de Belgique..., op. cit., p. 114.

${ }^{17}$ M. Krajzman, op. cit., pp. 33-35 ; W. Laqueur, A History of Zionism, New York, 1972, pp. 371419.
} 
(Arbeiders van Zion) de zionistische scène in België. Poale Tsion behield een licht overwicht tot in 1939. Toen dienden de Algemene Zionisten een coalitielijst in met de religieuze zionisten van Misrakhi en drukte de eerste deelname van de Linke Poale Tsion (Linkse Arbeiders van Zion, zie verder) het stemmenaantal van de Poale Tsion naar omlaag.

In Antwerpen was het zionisme niet alleen ouder en sterker ingeplant dan in Brussel, het bleef er vooral in de tussenoorlogse periode nog door de burgerlijke en religieuze stromingen beheerst. In 1939 behaalden de Algemene Zionisten en Misrakhi in Antwerpen samen nog $65 \%$ van de stemmen voor het Zionistisch Wereldcongres. In 1939 zamelde het fonds dat geld bijeenbracht voor de aankoop en de bewerking van gronden in Palestina, Keren Kayemeth Leisrael, in België 809.257 frank in, waarvan 66\% in Antwerpen en 27\% in Brussel $^{18}$. Bij de verkiezingen voor het Zionistische Wereldcongres in 1939 werden op een totaal van 3.812 stemmen $50 \%$ uitgebracht in Antwerpen en 44\% in Brussel, terwijl 54\% van de shekels (penning die werd betaald als lidmaatschapsgeld van een zionistische vereniging en die stemrecht gaf voor het Zionistisch Wereldcongres) in Antwerpen werden verkocht tegenover $40 \%$ in Brussel.

Tegelijk met de gestage groei van de beweging veranderde in de jaren na de Eerste Wereldoorlog het zionisme in België onder invloed van de nieuwe migratie van karakter. Tot 1920 werden de artikels in Hatikwah (Hoop), het weekblad van de BZF, overwegend in het Duits geschreven. Dit wijst erop dat het zionisme in België zijn ontstaan te danken had aan de burgerlijke-geëmancipeerde immigranten die vanaf het laatste kwart van de 19de eeuw uit Oost-Europa en in het bijzonder Oostenrijks Galicië naar België waren gekomen. Daarna verschenen er meer en meer teksten in het Frans en in 1936 nam het blad de titel L'Avenir juif aan.

Naast de belangrijke liberale strekking (de Agudath Tsion in Antwerpen en de Zionistische Unie in Brussel) en de religieuszionistische beweging (Misrakhi), eiste het arbeiderszionisme voortaan een plaats op. Tegen 1939 behaalden Poale Tsion - Tseiré Tsion en Linke Poale Tsion samen $47 \%$ van de stemmen voor het Zionistisch

${ }^{18}$ Cegesoma, MS10, Rapport Ehlers, p. 12. 
Wereldcongres ${ }^{19}$. Het arbeiderszionisme was toen dominant geworden in Brussel (56\%), maar niet in Antwerpen (35\%). In Luik en Charleroi behaalden ze samen respectievelijk $48 \%$ en $97 \%$.

Dit arbeiderszionisme vormde lang niet één blok. In feite kan er een dubbel spanningsveld in worden onderkend: reformisten versus revolutionairen en voorstanders versus tegenstanders van een activiteit die vooral, zo niet exclusief, op de emigratie naar Palestina (Eretz Israël) was gericht. Zo schonk de Poale Tsion een ruime aandacht aan de emigratie naar Palestina - tendens die werd versterkt door de samenwerking en later samensmelting met Tseiré Tsion. Dat was nog duidelijker het geval voor de extreem-nationalistische en al even extreem-linkse pioniersvereniging Hashomer Hatsair die weigerde om zich aan enige galut-werking te "bezondigen". Daar tegenover stond de afwijzing van de Linke Poale Tsion om zich aan de voorbereiding van de aliyah te wijden. Deze tegenstelling doorkruiste tot het midden van de jaren dertig de reformistisch-revolutionaire tegenstelling.

In 1921 werden in België zowel de Poale Tsion als de Linke Poale Tsion opgericht ${ }^{20}$. In de nasleep van de Oktoberrevolutie van 1917 was de internationale zionistische arbeidersbeweging in drie stromingen uiteengevallen : een eerste groep socialisten die in 1923 aansloot bij de Socialistische Internationale, een tweede revolutionair-marxistische groep die zich kon vinden in de politiek van de Komintern maar vasthield aan een autonome joodse organisatie en tenslotte een derde groep die opteerde voor aansluiting bij de nationale communistische partijen.

Aansluitend bij de toetreding van de Poale Tsion tot de Socialistische Internationale in 1923, ontstonden vrij nauwe banden tussen deze partij en de Belgische Werkliedenpartij (BWP). Een aantal van de belangrijkste BWP-leiders, in het bijzonder Émile Vandervelde, Louis De Brouckère en Camille Huysmans, waren het arbeiderszionisme genegen ${ }^{21}$. De Antwerpse advocaat Léon Kubowitzki, leider

\footnotetext{
${ }^{19} L^{\prime}$ Avenir juif, $\mathrm{n}^{\circ} 165,4.8 .1939$.

${ }^{20}$ M. Krajzman, op. cit., p. 33.

${ }^{21}$ D. Dratwa, «Émile Vandervelde on Zionism and the Jewish Question », dans Studies in Zionism, X-1, 1989, pp. 1-17 ; É. Vandervelde, Sur la Question juive et le sionisme. Écrits rassemblés et commentés par Daniel Dratwa, Bruxelles, 1987.W. Geldof, « Camille Huysmans en het Joodse
} 
van de Poale Tsion en één van de leidende figuren van de zionistische beweging in België, werd in 1932 verkozen als socialistisch gemeenteraadslid in Antwerpen. Vooral in Brussel traden een aantal Poale-zionisten op het voorplan: Estelle Goldstein was één van de leidsters van de BWP-federatie, Alice Pels was hoofdredactrice van het blad voor de socialistische vrouwen La Voix de la Femme en redactrice van Le Peuple, David Katz tenslotte was hoofdredacteur van L'Étudiant socialiste.

In 1932 smolt Poale Tsion in België samen met de sociaaldemocratische beweging Tseiré Tsion om de Poale Tsion - Tseiré Tsion te vormen. Vaak werd de partij angeduid als joodse Socialistische Partij. De oorsprong van Tseiré Tsion (Jeugd van Zion) was niet dezelfde als deze van Poale Tsion. In feite had de zionistische linkerzijde een tweeledige oorsprong: de zionistische tak van de sociaal-democratische arbeidersbeweging in Oost-Europa enerzijds en de socialistische- en pionierstak van de zionistische beweging anderzijds. Tseiré Tsion situeerde zich ter linkerzijde van de algemene zionistische beweging, met als doelstelling de onmiddellijke emigratie naar Palestina te organiseren.

De joodse Socialistische Partij organiseerde vanaf 1933 een eigen pioniersbeweging, Dror (Vrijheid), die afdelingen telde in Antwerpen, Brussel, Charleroi, Luik en Seraing22. In Brussel was daarnaast de jeugdbeweging Gordonia sinds 1929 actief. Samen met Hashomer Hatsair, Hechaluts, Gordonia en Dror vormde de Joodse Socialistische Partij de Liga voor het Arbeidende Palestina. Toen België in 1927 voor het eerst apart werd genoteerd bij de tweejaarlijkse verkiezingen voor het Zionistisch Wereldcongres, behaalde de Poale Tsion in coalitie met Tseiré Tsion 15,7\% van de stemmen. In 1929 was dat 21,5\%, in 1931 26,2\%, in $193333,9 \%$ en in 1935 47,5\%. Daarmee was de Poale Tsion vanaf 1933 belangrijker dan de liberale Algemene Zionisten en meteen de sterkste zionistische formatie. In 1937 werden er in België geen verkiezingen georganiseerd voor het Zionistisch Wereldcongres, maar in 1939 viel de Poale Tsion, vermoedelijk door de eerste deelname van

\footnotetext{
Volk : een vriendschap voor het leven », in Bijdragen tot het Camille Huysmansonderzoek, 1971, pp. 211-257.

${ }^{22}$ M. Krajzman, op. cit., p. 34-35 ; Cegesoma, MS10, Rapport Ehlers, Das Judentum in Belgien, Sipo-SD, 31 januari 1942, p. 15.
} 
de Linke Poale Tsion, op 29\% terug. Uit deze verkiezingsuitslagen blijkt ook dat de Poale Tsion wat sterker was ingeplant in Antwerpen dan in Brussel (respectievelijk 27\% en 24\%), maar ook dat de partij de zionistische scène beheerste in Charleroi $(85 \%)^{23}$.

De concurrentie tussen de linkse en rechtse Poale Tsion bestond vooral in Brussel. In Antwerpen vormde de Poale Tsion als enige een trouwens relatief zwak - tegenwicht tegen het liberale en religieuze zionisme. De Linke Poale Tsion, die nauwelijks iets betekende in Antwerpen (8\% van de stemmen in 1939), was er in Brussel wel in geslaagd een wezenlijke aanhang te verwerven $(32 \%$ van het zionistische electoraat in 1939). In tegenstelling tot de andere socialistisch-zionistische bewegingen telde de Linke een reële aanhang onder de joodse arbeiders in Polen, waar het een aantal syndicale groepen controleerde ${ }^{24}$. Het was dank zij de inwijking uit Polen en de inbreng van studenten-intellectuelen, dat de Linke Poale Tsion haar invloed in de Brusselse migratie kon bestendigen. In 1926 richtte de Linke in Brussel de jeugdgroep Yung Bor (naar de stichter van de partij Ber Borochov) op en een jaar later de sportclub Shtern (Ster), gevolgd door een clubhuis Unzer Haym (Ons Huis) in Antwerpen ${ }^{25}$. Op syndicaal vlak verwierf de partij heel wat invloed onder de marokijnarbeiders in Brussel ${ }^{26}$.

Net als over de meeste aspecten van deze geschiedenis van het zionisme in België, is er ook over de "Belgische" bijdrage aan de joodse vestiging in Palestina nog weinig onderzoek beschikbaar. Bekend is dat er jaarlijks bij de BZF slechts een tiental officiële certificaten voor vestiging in Palestina beschikbaar waren en er zich niet zelden een honderdtal kandidaten aanmeldden. Sommigen, in het bijzonder de

\footnotetext{
${ }^{23}$ Protokoll der Verhandlungen des XV. Zionistenkongresses, Basel, 30.8 - 11.9.1927, p. 19; Protokoll der Verhandlungen des XVI. Zionistenkongresses, Zurich, 28.7 - 14.8.1929, p. 17; Stenographisches Protokoll der Verhandlungen des XVII. Zionistenkongresses, Basel, 30.6-17.7. 1931, p. 17 ; Stenographisches Protokoll der Verhandlungen des XVIII. Zionistenkongresses, Prag, 21.8-4.9.1933, pp. 20-21; Stenographisches Protokoll der Verhandlungen des XVIII. Zionistenkongresses, Luzern, 20.8-6.9.1935, pp. 22-23; Verslag van de werkzaamheden van het XXste Zionistisch Congres, Zurich, 3-21.8.1937; L’Avenir juif, n 165, 4.8.1939.

${ }^{24} \mathrm{~N}$. Weinstock, Le pain de misère. Histoire du mouvement ouvrier juif en Europe. I. L'Empire russe jusqu'en 1914, p. 99.

${ }^{25}$ Ibid., p. 145.

26 M. Steinberg, L'étoile et le fusil, tome 2 : 1942 : Les cent jours de la déportation des Juifs de Belgique, Brussel, 1984, pp. 120-121.
} 
extreem-linkse pioniers van de Hashomer Hatsair, lieten zich hierdoor niet afschrikken en immigreerden illegaal.In het algemeen speelden de jeugdbewegingen in het zionisme een toonaangevende rol. Zo goed als alle tendensen bezaten hun eigen jeugdgroepen, sommigen in de vorm van scouts/pioniers die zich in de praktijk voorbereidden op een emigratie naar Eretz Israël. Naast de diverse linkse jeugdgroepen zagen tussen het midden van de jaren en twintig en het midden van de jaren dertig diverse politiek neutrale zionistische jeugdgroepen het levenslicht, naast een liberale (Maccabi Hatsair), een religieuze (Bnei Akiva) en een extreem-rechtse (Beitar) groep. Het waren echter slechts de uitgesproken linkse pioniersbewegingen die ook direct de daad bij het woord voegden.

In 1927 werd een eerste collectieve hachshara (voorbereiding) georganiseerd en in 1929 vertrok een eerste groep van de Belgische Hashomer Hatsair naar Palestina ${ }^{27}$. Eind 1931 werden zij vervoegd door 18 pioniers die zich in Palestina verenigden met een groep uit Polen. Na een tijdelijk verblijf in Hedera lagen zij aan de basis van de oprichting van de eerste "Belgische" kibboets Ein Hachoresh. In 1939 werd de kibboets Dan gesticht, eveneens door leden van de Hashomer Hatsair uit België. Bekend is ook dat er midden de jaren 1930 door een aantal zionistische pioniersbewegingen in Villers-la-Ville, ten zuiden van Nijvel, een voorbereidingscentrum werd ingericht.

Ook het liberale zionisme onderging na de Eerste Wereldoorlog een belangrijke evolutie. Van oppositiebeweging tegen het Belgisch Israëlitisch Jodendom, werd het zelf in zekere mate een onderdeel van het joods establishment.Deze "verovering" van de Belgisch-joodse structuren werd ondersteund door de gestage opgang van het zionisme. In 1931 smolt in Antwerpen de zionistisch georiënteerde Gemeente Shomré Hadass samen met de Israëlitische Gemeente van "Hollandse" ritus $^{28}$. Tezelfdertijd werden Joseph Wiener aangesteld tot opperrabbijn en Avigdor Amiel tot rabbijn in Antwerpen29. Beiden waren het zionisme genegen. In 1932 werd een nieuw joods blad

\footnotetext{
${ }^{27}$ J. Stamberger, Be Strong and Brave! A small Youth Movement in a Sea of History. The Hashomer Hatzair Antwerp (1920-1948),UGent masterscriptie, 2013, p. 67 e.v. Lees artikel van Janiv Stamberger in onderhavige Bijdragen.

${ }^{28}$ E. Schmidt, Geschiedenis van de joden in Antwerpen, Antwerpen, 1963, p. 92.

${ }^{29}$ J.-Ph. Schreiber, Les Juifs de Belgique..., op. cit., p. 66 e.v.
} 
opgericht met de sprekende titel L'Alliance, dat zich tot doel stelde een brug te slaan tussen de zionistische en Israëlitische stromingen ${ }^{30}$. Vanaf 1933 vonden beiden elkaar ook in het door Max Gottschalk opgerichte Hulp- en Steuncomité voor de Slachtoffers van het Antisemitisme in Duitsland. In 1935 kregen Numa Torczyner, voorzitter van de Belgische Zionistische Federatie en leider van de Agudath Tsion, en Bentzel Averbouch, ondervoorzitter van de Zionistische Unie, zitting in het bestuur van het Centraal Israëlitische Consistorie van Belgiē ${ }^{31}$.

\section{De joodse communisten}

Naast het zionisme manifesteerde zich een tweede belangrijke stroming in de joodse samenleving van de tussenoorlogse jaren, namelijk het communisme.De socialistische en antizionistische Bund speelde in de immigratie een beperkte rol ${ }^{32}$. De Bund, die de oudste en veruit belangrijkste joodse arbeidersorganisatie in Oost-Europa was, slaagde er nooit in bij de Belgische immigranten een soortgelijke positie te verwerven. In 1920 werd een kern actief in het Brusselse, maar die bleef klein en permanent het voorwerp van ledenverlies, eerst aan de communisten, later aan de trotskisten ${ }^{33}$. In wezen school hierin ook een generatiekwestie : de Bund-leden waren door de band één generatie ouder dan de communisten.

De Oktoberrevolutie van 1917 liet op vele Joden in Oost- en Centraal Europa een grote indruk na. Zij geloofden in de gelijkheid van alle mensen als oplossing van het joods probleem en waren grote voorstanders van de joodse assimilatie. Het kapitalisme was voor hen de grote vijand en de bron van alle onheil, ook voor de Joden. Vanaf het midden van de jaren twintig manifesteerden de joodse communistische migranten zich op de scène van het Jiddischland in België. Zij stichtten verenigingen en profileerden hun relatie met de Belgische

\footnotetext{
${ }^{30}$ Ibid.

${ }^{31}$ Ibid, p. 90.

${ }^{32}$ A. Caratsch-Gattiker, « Jean Arens, diplomate soviétique : Bund, bolchévisme et purge », in Communisme, $\mathrm{n}^{\circ} 17,1988$, pp. 128 sqq.

${ }^{33} \mathrm{Cl}$. Prowizur-Szyper, Conte à rebours. Une résistante juive sous l'occupation, Bruxelles, 1979, p. 26.
} 
communisten. Het was de Communistische Internationale in Moskou die de wijze van organiseren en de politieke boodschap vastlegde. Tussen 1928 en 1935 voerden de communisten een extreme klassenstrijdpolitiek en werden de socialisten de meest geviseerde tegenstanders. Na 1935 zochten de communisten, door middel van een Eenheids- en Volksfrontpolitiek, met de meest diverse democratische krachten allianties aan te gaan tegen het fascisme. Deze strategieën bepaalden tevens de opstelling van de communisten in de joodse kwestie.

Tijdens die eerste periode voerden de joodse communisten een eenzame strijd tegen alles en iedereen. Zij manifesteerden zich als extreme tegenstanders van de traditionele, door de godsdienst gedomineerde, joodse leefwereld. Al evenzeer stelden zij zich vijandig op tegen het zionisme, met inbegrip van het linkse zionisme. Ook de socialistische Bund vond in hun ogen geen genade, want deze partij stond symbool voor het z.g. "sociaal-fascisme" dat de arbeiders verzoende met het kapitalisme. Slechts in de vrijgevochten en ongebonden wereld van de joodse studenten aan de Gentse, Luikse en Brusselse universiteiten hielden de revolutionairen, ondanks de zionistische dominantie, goed stand. Hun enige echte succes boekten de communisten in die periode van klasse-tegen-klassepolitiek bij de meest radicaal linkse en zionistische pioniers van de Hashomer Hatsair in Antwerpen. Uit de rangen van die organisatie kwamen de belangrijkste communistische voormannen van de tweede helft van de jaren 1930.

Ook tijdens die eerste periode werden de communistische vreemdelingenorganisaties volgens het bolsjewistische model gereorganiseerd. Deze bolsjewisering bracht op twee vlakken spanningsvelden aan het licht tussen de identiteit van de joodse migranten en de communistische doctrine. Het eerste spanningsveld kwam tot uiting toen de partijleiding de joods-communistische volksclub Kultur Fareyn wenste op te doeken ${ }^{34}$. Uit het verzet hiertegen van de joodse communistische migranten bleek dat die club voor hen meer dienst deed als een alternatieve synagoge dan als een communistische massaorganisatie. Deze culturele eigenheid vertaalde zich ook in het

${ }^{34}$ N. Weinstock, op. cit., pp. 184-185. 
behoud van een joods ambachtelijk en mercantiel beroepsprofiel.Hierin school volgens de communistische partijleiding de oorzaak van de z.g. "nationalistische" en "kleinburgerlijke" afwijkingen van de joodse partijleden.

De rol van de joodse communisten kwam pas echt op de voorgrond toen als gevolg van de economische depressie de invloed van de communisten zowel in België als in het buitenland steeg. Internationale spanningen en toenemend antisemitisme wogen zwaar op de joodse migrantengemeenschap. Het Volksfront vierde overwinningen in Frankrijk, maar straalde via de politieke richtlijnen van de Communistische Internationale ook af op de joodse communisten in België. De joodse communisten stuurden hun visie op het nationalisme bij en veranderden hun aanpak van de syndicale- en middenstandsproblematiek. Zij slaagden er daardoor in tot een bescheiden samenwerking te komen met de socialistische Bund en de linkszionistische partijen. Vooral echter lagen ze aan de basis van een gamma van joodse organisaties die hun invloed verankerde in een veel breder segment van het Belgische Jiddischland.

De joodse accenten die tijdens de Volksfrontperiode werden gelegd, zijn belangrijk, omdat zij in feite niet te rijmen vallen met de communistische assimilatietheorie als enig mogelijke oplossing voor het joods probleem. In de politieke realiteit gebeurde er iets anders en dat was, net als voor de spanningsvelden van voor 1935, het gevolg van de culturele instelling van de Oost-Europese joodse migranten.

De door de communisten opgerichte sport- en cultuurverenigingen, zoals de Joodse Arbeiders Sportclub (JASK) in Antwerpen en de sportclub Eynheyt in Brussel, verwierven een belangrijke plaats in de joodse gemeenschap. Daarnaast konden ook de propagandaclubs voor Birobidjan (het door Stalin in Oost-Siberië gecreëerde thuisland voor Joden), achtereenvolgens Gezerd en Prokor geheten, op heel wat sympathie rekenen ${ }^{35}$. Ook bleven de communisten zeer actief in de Patronatn (naar het Italiaanse Patronati), de clubs die migranten uit bepaalde steden of regio's samenbrachten ${ }^{36}$. De inzet voor de Spaanse

35 S. Cukier, D.Decèze, D.Diamant, M. Grojnowski, Juifs révolutionnaires. Une page d'histoire du Yidichland en France, Paris, 1987, p. 85.

${ }^{36}$ Parti communiste (SFIC), L'importance de la MOE et les diverses immigrations. Bulletin spécial d'informations de la section centrale de la MOE, zonder datum noch plaats, p. 46; A. Morelli, 
Republiek tijdens de burgeroorlog was in alle opzichten merkwaardig. De antifascistische idealen konden vele joodse migranten bekoren en zo'n 200 onder hen trokken, omkaderd door de communisten, als vrijwilligers naar Spanje om te vechten in de Internationale Brigaden.

In de schaduw van deze brede verenigingen bleef een kleine groep joodse partijleden actief die georganiseerd waren in de MOI (Main d'Cuvre Immigrée) en die de ordewoorden van de Communistische Partij van België gestalte gaven. De Jiddische secties van de MOI, die Jiddisch sprekenden verzamelden uit hoofdzakelijk Polen, de Baltische Staten, Galicië, Wit-Rusland en de Oekraïne waren veruit de belangrijkste. Daarnaast waren er ook de Hongaarse en Bessarabische secties, die voor het overgrote deel (en in Antwerpen uitsluitend) uit Joden bestonden. De invloed van de joodse communisten verdeelde zich over Antwerpen en Brussel, met toch een licht overwicht voor de hoofdstad. Op basis van diverse elementen kan de aanhang van de joodse communisten in België op zo'n 2.000 personen geschat worden tijdens de periode 1936-1939.

Het is op sociaal terrein, in de syndicale belangenverdediging, dat de communisten na 1935 het meest op de voorgrond $\operatorname{traden}^{37}$. In de kleding, in de voeding - de joodse bakkerijen en slagerijen - en de diamantsnijderijen werkten de joodse arbeiders thuis of in kleine ateliers, hoofdzakelijk voor joodse patroons. In die sectoren organiseerden de communisten een haast corporatieve, pre-industriële belangenbehartiging, op een wijze die in bepaalde opzichten herinnert aan de eerste syndicale organisaties van ambachtslui in België rond het midden van de 19de eeuw. Mutualistische initiatieven zagen het licht, net als leenkassen. Ook opvallend was de bijna monopoliepositie van de joodse vakbondsgroep in de voeding. Daarnaast ontstonden er professionele verenigingen voor ambachtslui, leurders en marskramers die door de communisten werden gepatroneerd. Een scherpe scheidingslijn tussen die "middenstandsverenigingen" en de parallelle "syndicale groepen" was in het Jiddischland van de jaren dertig sociaal

Fascisme et antifascisme dans l'immigration italienne en Belgique (1922-1940), doctoraatsthesis, ULB, 1985, pp. 99-115.

${ }^{37}$ I.v.m. de algemene aspecten, cfr : G. Harmsen, « Kommunistische vakbewegingspolitiek tussen de wereldoorlogen », in G. Harmsen, Nederlands kommunisme. Gebundelde opstellen, Nijmegen, 1982, pp. 91-137. 
noch politiek te trekken. Enkel bij de Antwerpse diamantzagers telden de joodse communisten aanhang in een industrieel milieu, maar dat was dan in hoofdzaak niet onder Oost-Europese maar onder Nederlandse Joden.

In de Metropool vormden de communisten de enige groep van betekenis in de joodse linkerzijde. Een eenheidsfront met andere linkse groepen behoorde dus niet tot de mogelijkheden, terwijl ze in de tweede helft van de jaren 1930 door de solidaire opstelling van de joodse rechterzijde uit een joods front werden geweerd. In Brussel sloegen de communisten eerst de weg in van een aarzelend "arbeiderseenheidsfront" met de socialistische Bund, om bij het uiteenspatten daarvan over te stappen naar een breed front van de joodse migratie ${ }^{38}$.

Ondanks al deze verschillen, hadden de joodse communisten zich door de Volksfrontpolitiek minder sektarisch opgesteld, wat een doorbraak naar de joodse migrantengemeenschap had mogelijk gemaakt. $\mathrm{Zij}$ waren er, net als de zionisten, in geslaagd om hun invloed systematisch uit te breiden. Die invloedsuitbreiding situeerde zich niet enkel onder de kleiner wordende groep loontrekkende joodse arbeiders, maar ook - en dit was toch een opmerkelijk verschil met de eerste helft van de jaren dertig - onder wat wij gewoonlijk middenstandsgroepen noemen : zelfstandige ambachtslui, marskramers, leurders en kleine handelaars.

\section{In de schaduw van het nazisme}

Het aan de macht komen van de NSDAP in Duitsland in 1933 en de vervolging van de Joden die daarop volgde beïnvloedde ook aanzienlijk de joodse gemeenschap in België. In diezelfde periode namen ook de sociale spanningen toe door de economische crisis en parallel daaraan bloeide het antisemitisme op. De opvang van duizenden joodse vluchtelingen uit Duitsland en later ook uit Oostenrijk woog zwaar op de joodse gemeenschap in België en wijzigde ook de politieke opstelling van de gemeenschap en haar relatie met de overheid en de bevolking.

38 N. Weinstock, op. cit, p. 144. 
Door deze gebeurtenissen werden in de tweede helft van jaren 1930 de zionisten gedwongen tot het minstens deels verleggen van hun prioriteiten naar de concrete problemen van de joodse bevolking in België. Daardoor ging hun invloed nog in stijgende lijn, werden de relaties met de traditionele Gemeenten aangehaald en kwam de joodse gemeenschap in haar geheel zeker dichter bij elkaar. Zelfs de joodse communisten zochten op hun manier toenadering.

In deze heroriëntatie van het zionisme speelde het arbeiderszionisme onder de leiding van Léon Kubowitzki een voortrekkersrol. Zo lag het aan de basis van het Comité tot verdediging van de Rechten der Joden (opgevolgd door VEVA, het Verbond voor Economisch Verweer - Antwerpen) en het Comité d'Action économique in Brussel, die vanaf 1933 opkwamen voor een boycot van producten uit Duitsland. Deze boycot bleef echter om verschillende redenen, o.m. de verdeeldheid in joodse rangen, zonder concrete gevolgen voor nazi-Duitsland. In de daaropvolgende jaren werd het actieterrein van deze comités uitgebreid tot de strijd tegen het antisemitisme en werd geijverd voor de oprichting van een Joods Wereldcongres.

Het Comité tot Verdediging van de Rechten der Joden ontfermde zich in Antwerpen ook over de vele joodse vluchtelingen die uit Duitsland toestroomden. Het comité was in wezen een samenwerking tussen de zionistische beweging en de orthodoxe Joden in de Scheldestad. Voor de materiële hulp werkte het nauw samen met het Centraal Beheer voor joodse Weldadigheid en maatschappelijk Hulpbetoon. In Brussel werd in 1933 het Comité d'Aide et d'Assistance aux Victimes de l'Antisémitisme en Allemagne (CAAVAA) opgericht. In 1938 werd het tot Comité d'Assistance aux Réfugiés juifs (CARJ) omgedoopt. Het CAAVAA werd geleid door de hoge ambtenaar Max Gottschalk die tevens ondervoorzitter was van de Israëlitische Gemeente van Brussel $^{39}$. Deze humanitaire activiteit vertaalde eigenlijk de verschillende krachtsverhoudingen in de beide steden met een grote joodse bevolking. In Antwerpen was tegen de jaren 1930 het liberale en

\footnotetext{
39 J.-Ph. Schreiber, «L'accueil des réfugiés juifs du Reich en Belgique, mars 1933-septembre 1939 : le Comité d'Aide et d'Assistance aux Victimes de l'Antisémitisme en Allemagne », dans Les Cahiers de la Mémoire contemporaine, 3, 2001, pp. 23-71.
} 
religieuze zionisme dominant geworden, in Brussel bleven de traditionele Belgische kringen van het Consistorie een factor van grote betekenis.

De toenemende aandacht van alle zionistische groepen voor de belangenbehartiging van de Joden in de Belgische migratie kwam, in het verlengde van het Joods Wereldcongres, eveneens tot uiting in de sleutelrol die zionisten speelden bij de oprichting in december 1937 van de Raad der Joodse Verenigingen van Brussel en in mei 1938 van de Algemene Raad der Joodse Organisaties van Antwerpen. Deze Raden waren ontstaan om de collectieve belangen van de Joden in deze tijden van antisemitische dreiging te verdedigen. In Brussel verenigde de Raad zo goed als alle stromingen van de joodse immigratie, van de orthodoxen tot de communisten. In Antwerpen, waar de Raad nooit echt van de grond kwam en de krachtsverhoudingen anders lagen, werden de communisten geweerd. In de Brusselse Raad werd de kwestie van het zionisme, ondanks de leidende rol van de zionisten, als niet behorend tot de bevoegdheid van de Raad terzijde gelaten. Dat was tekenend voor de gewijzigde houding van de zionisten.

De politiek van het CAAVAA bestond erin, in aansluiting bij de politiek van de Belgische overheid, de vluchtelingen tijdelijk onderdak en bijstand te verlenen en tegelijkertijd te ijveren voor hun remigratie. Enkel de vluchtelingen die economisch interessant konden zijn voor België, vormden een uitzondering op deze regel. Voor zijn humanitair werk ontving het Comité omvangrijke steun uit het buitenland, in het bijzonder van de Joint (American Jewish Joint Distribution Committee)uit de VSA. Vooral na de uitvaardiging van de wetten van Neurenberg in 1935 nam het aantal vluchtelingen sterk toe. Vele zionisten, onder wie Léon Kubowitzki, waren het met dit "wachtkamerbeleid" niet eens.Ondanks hun ideologische tegenstellingen zouden de twee comités onder druk van de desastreuze omstandigheden waarin vele vluchtelingen zich bevonden, tegen het einde van jaren 1930 toch samenwerken. Begin 1940 hadden beide niet minder dan 15.000 vluchtelingen onder hun hoede. Ondertussen waren er door de regering trouwens opvangkampen ingericht omdat de financiële last ondraaglijk was geworden. Dat was het geval in Merksplas en Marneffe, waar kampen werden beheerd door het CARJ, 
en Wortel, dat werd beheerd door het Antwerpse Comité. Later kwamen daar nog Marchin en Eksaarde bij ${ }^{40}$.Samen verbleven er op 1 januari 1940 ongeveer 1.400 vluchtelingen in deze centra. Toen kwam het vluchtelingenbeleid steeds meer onder druk te staan door de oorlogsdreiging en het veiligheidsstreven dat ermee gepaard ging. Dit leidde uiteindelijk, na de Duitse inval in België, tot de aanhouding van vele duizenden (schattingen variëren van 13.500 tot 16.000) joodse vluchtelingen uit Groot-Duitsland als vijandige onderdanen. 7.500 onder hen werden naar Franse kampen weggevoerd.

De mislukking van de collectieve veiligheidspolitiek van de SovjetUnie en de nederlaag van de Spaanse republiek in februari 1939 , leidden een proces in dat uitmondde in het Sovjet-Duits nietaanvalspact van augustus 1939. Met uitzondering van de Raad der Joodse Verenigingen, was de samenwerking van de joodse communisten met andere joodse verenigingen, ook in Brussel, in het voorjaar van 1939 minimaal geworden. De enige partner van de communisten, de Linke Poale Tsion, die voorheen steeds aan de rand van de zionistische beweging had gestaan, was in 1938 toegetreden tot de Belgische Zionistische Federatie en was tegelijkertijd ook een van de actiefste krachten geworden in de Raad ${ }^{41}$. De politieke evolutie van de late jaren dertig had in deze heroriëntatie van de extreem-linkse zionisten een belangrijke rol gespeeld : de zeer sterke dreiging die na de Kristallnacht begon te wegen op de Joden in Europa, de algemene verrechtsing van het klimaat en het toenemende antisemitisme in België en ten slotte de Arabische anti-joodse opstand in Palestina in de jaren 1936-1938. Het resultaat van deze nieuwe opstelling van de Linke Poale Tsion - die in 1939 32\% van de zionistische stemmen haalde in Brussel - was dat de zionistische stroming in Brussel de dominerende kracht werd in de joodse gemeenschap op het einde van de jaren dertig. Hiermee sloot Brussel aan bij Antwerpen, waar die zionistische dominantie al in de eerste helft van de jaren 1930 was tot stand gekomen.

\footnotetext{
${ }^{40}$ N. Van Campenhout, « Joodse vluchtelingen in Eksaarde [Lokeren] (1939-1940) », Annalen van de Koninklijke Oudheidkundige Kring van het Land van Waas, 2008, pp. 253-261.Y. Pluym, De Rijksweldadigheidskoloniën te Merksplas ten tijde van het Interbellum. Vrijheidsberoving en liefdadigheid, licentiethesis, UGent, vakgroep geschiedenis, 2004.

${ }^{41}$ J.-Ph. Schreiber, Les Juifs de Belgique..., op. cit., p. 117.
} 
Door de ondertekening van het Stalin-Hitlerpact op 23 augustus 1939 werd achter de communistische eenheidswerking met andere joodse partijen een punt gezet. De joodse communisten kwamen zo opnieuw in een totaal isolement t.a.v. de joodse gemeenschap te staan. In het najaar van 1939 werd Yidishe Solidaritet (Joodse Solidariteit) gesticht om de eigen militanten en sympathisanten te steunen. Het was vanuit deze Yidishe Solidaritet dat in het najaar van 1942 een nieuw "front" werd uitgebouwd dat leidde tot de creatie van het Comité de Défense des Juifs (Joods Verdedigingscomité) in Brussel. Het CDJ speelde later een kapitale rol in de organisatie van het verzet tegen de anti-joodse maatregelen van de Duitse bezetter.

\section{De gouden jaren van het Jiddische leven}

De joodse gemeenschappen in België vertoonden in de periode tussen de twee wereldoorlogen een aantal opvallende tegenstrijdigheden.

Op sociaaleconomisch vlak bleven zij in de joodse sectoren actief en cultureel bleef het Jiddisch en de Jiddische eigenheid dominant. Dit kwam ondermeer tot uiting in de bloei van Jiddische pers. Geen groep migranten vertoonde een dergelijke uitgesproken neiging tot clubvorming, of, om het met een moderne term uit te drukken, tot verzuiling, dan de joodse. Dat uitte zich in het buitengewoon bloeiende verenigingsleven.

Maar deze gehechtheid aan de traditie werd doorkruist door nieuwe ideeën en gedragspatronen. De sterk verspreidde en soms radicale secularisering was daarvan de duidelijkste illustratie. Niettemin kon zelfs bij de meest radicale voorstanders van de assimilatie, de joodse communisten, een gehechtheid aan de joodse cultuur vastgesteld worden. De joodse migrant was mentaal onderweg om de kaftan af te leggen, terwijl nog geen nieuwe moderne joodse identiteit vaste vorm had gekregen.

Op politiek-ideologisch vlak werd de minderheid van Belgische Israëlitische Joden, die meestal een liberaal gedachtegoed aanhingen en zich sterk betrokken voelden bij de Belgische natie, overschaduwd door de meerderheid van nieuwe migranten uit Oost-Europa. De kringen van het Israëlitisch Consistorie en de traditionele Gemeenten 
trachtten de immigranten door caritatieve projecten en scholing te integreren. Daarbij betrokken zij ook vertegenwoordigers van het burgerlijke zionisme, zonder echter hun geloof in de assimilatie op te geven.

Naast de religieus-orthodoxe minderheidsgroep manifesteerden zich tijdens de jaren 1920 en 1930 twee dominante strekkingen in de joodse migratie : het zionisme en het communisme. Beide stromingen werden gekarakteriseerd door een heilsideaal en door een intense solidariteit en samenhorigheid onder de leden. Deze eigenschappen boden het nodige psychologische houvast aan deze nog niet echt geëmancipeerde en door de migratie ontwortelde generatie.

De joodse gemeenschappen in België tijdens het interbellum werden wellicht het meest gekarakteriseerd door hun streven naar integratie in de Belgische samenleving.Dit betekende niet dat de Oost-Europese Jood zijn cultuur wenste te verloochenen of de assimilatie op het model van de Belgisch-joodse elite voorstond. Wel overheerst de indruk dat in die jaren tussen de twee wereldoorlogen zelfs de meerderheid van de zionistische nationalisten België niet als een transithall zag met het oog op de emigratie naar Palestina. Dit integratiestreven werd vertolkt door het liberaal- en arbeiderszionisme voor de kleine handelaar, ambachtsman of zelfstandige ondernemer en door de communistische sociale strijd voor de arme en ontwortelde migrant. De meeste Joden hadden daarbij ongetwijfeld hetzelfde doel voor ogen : het opbouwen van een menswaardig bestaan in België.

Door de tragische gebeurtenissen van de Tweede Wereldoorlog zou de joodse bevolking in een heel nieuwe context terechtkomen. Ondanks de armoede en de oorlogsdreiging in de periode tussen de twee wereldoorlogen, kwamen, zo kan men ze achteraf toch wel bestempelen, deze gouden jaren van het Jiddische leven in België nooit meer terug. 